\title{
BRUNO DUNLEY
}

"Eu tenho muita dificuldade de escolher o que pintar e, de certa forma, acho que essa dificuldade está virando um assunto." A indecisão sobre a qual comenta o artista Bruno Dunley o levou para caminhos distintos na busca de referências para a realização das pinturas que vem desenvolvendo desde que deixou de lado sua faculdade de fotografia para cursar artes plásticas, em São Paulo.

Além das influências captadas dos livros de história da arte e de poesia - dentre os quais há um exemplar de Estrela da vida inteira, de Manuel Bandeira, assinado pelo autor, que Bruno exibe entusiasmado -, um dos caminhos de investigação que ele desenvolveu foi a criação de um arquivo de imagens, que funciona como uma espécie de enciclopédia de temas e referências. Nesse compêndio, Bruno agrega não só figuras diretamente vinculadas ao campo das artes plásticas, mas também um número significativo de registros ligados a áreas como anatomia e botânica e que, posteriormente, ele verte em pinturas de dimensões variadas.

$\mathrm{O}$ artista também recorre à monocromia, que serve como base para a criação de seus quadros. Boa parte deles possui grandes dimensões e foi feita a partir de uma tinta amarela, cujos resquícios podem ser vistos em algumas obras da exposição apresentada agora no Centro Universitário Maria Antonia, intitulada simplesmente e.

Boa parte da investigação de Dunley está voltada para o hiato entre a experiência e a linguagem, algo que se reflete nas representações de elementos da comunicação, como nos quadros Braille e The ear: "O braille diz respeito ao que é tátil e que se mistura ao desejo tátil da pintura, é essa ideia da tinta como carne. Já no caso da The ear há uma inversão onde a própria pintura também está tendo uma expectativa de ouvir, mas ela tem uma cor que a deixa meio muda, meio silenciosa, uma metáfora de som, então acho que esbarra em algo que não é só visual".

Essa busca sensorial que Bruno propõe se complementa pelo tamanho dos trabalhos: enquanto identifica suas pinturas de menor dimensão como uma tentativa de esboço ou anotação, as obras maiores são pensadas como a construção de um corpo.

Outra importante questão relativa ao aspecto sensorial da produção de Bruno Dunley é a orientação, vertical ou horizontal, adotada em suas telas. "Geralmente o trabalho horizontal tem algo de paisagem, uma linha panorâmica. Já o vertical tem uma relação com o corpo humano, que é mais vertical do que horizontal.” 
Nos quadros exibidos no Maria Antonia, bem como em grande parte de sua produção, Bruno utiliza principalmente tinta a óleo, um material tradicional a que o artista mistura outros elementos, visando a consistência ideal. Para conseguir uma aparência opaca e acelerar a secagem das telas, que pode demorar até quatro dias, ele adiciona cera de abelha ou terebentina às tintas. $E$, em busca de um aspecto mais delicado, o tecido, antes lona 10, foi substituído pelo algodão. "Hoje eu uso um algodão entelado duas vezes. O algodão é fininho e eu dou quatro camadas de gesso e ainda lixo a tela. Eu gosto quando você olha o trabalho e não vê o pano, sabe?".

por Thierry Freitas e Lara Rivetti 